УДК 574.5:574.64

\title{
НОВЫЕ ДАННЫЕ О ХЛОРОРГАНИЧЕСКИХ ПОЛЛЮТАНТАХ В ПОДКОЖНОМ ЖИРЕ ЧЕРНОМОРСКИХ КИТООБРАЗНЫХ
}

Логоминова И. В. ${ }^{1}$, Малахова Л. В. ${ }^{2}$, Малахова Т. В. ${ }^{2}$, Артов А.М. ${ }^{1,}$ Коростелева А.В. ${ }^{3}$, Постникова А.Н. ${ }^{3}$

${ }^{1}$ ФГБУН «Карадагская научная станция им. Т.И.Вяземского - природный заповедник РАН», 2. Феодосия, пгт. Курортное, Российская Федерачия,

${ }^{2}$ ФГБУН «Институт морских биологических исследований имени А.О. Ковалевского РАН», 2. Севастополь, Российская Федераџия

${ }^{3}$ АНО «Центр изучения, спасения и реабилитации морских млекопитающих «Безмятежное море», Москва, Российская Федеращия e-mail:logominova@rambler.ru, malakh2003@list.ru,t.malakhova@imbr-ras.ru, aartov06@gmail.com, sereneseadolphins@gmail.com

Представлены данные о содержании хлорорганических пестицидов (ХОП) и полихлорированных бифенилов (ПХБ) в подкожном жировом слое черноморских дельфинов афалин, белобочек и морских свиней (азовок), выброшенных на крымское побережье в 2017 г. Во всех исследованных пробах обнаружены $\alpha$-, $\beta$ - и $\gamma$-ГХЦГ в интервале концентраций от 0,003

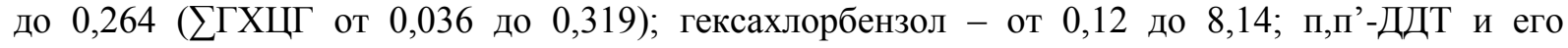
метаболиты п,п'-ДДЭ и п,п'-ДДД - от 0,08 до 146,95 ( $\sum$ ДТ от 1,27 до 163,18); а также шесть конгенеров полихлорбифенилов (по IUPAC: 28, 52, 101, 138, 153 и 180) - от 0,004 до 11,28 $\left(\sum \Pi Х Б_{6}\right.$ от 0,42 до 27,04$)$ мкг $\Gamma^{-1}$ липидной массы. Доля п,п'-ДДЭ составляла от 44 до $90 \%$ суммы ХОП и достигала 146,95 мкг $\Gamma^{-1}$ липидной массы. Максимальная концентрация ХОП и ПХБ зафиксирована в пробах подкожного жира белобочек.

Ключевые слова: морская свинья (азовка), афалина, белобочка, ГХЦГ, гексахлорбензол, ДДТ, ДДЭ, полихлорированные бифенилы, Черное море

\section{Введение}

К особо опасным загрязнителям морской среды относятся такие хлорорганические соединения (ХОС), как полихлорбифенилы (ПХБ) и хлорорганические пестициды (ХОП), среди которых наиболее распространенными являются устаревшие инсектициды гексахлорциклогексан (ГХЦГ) и дихлордифенилтрихлорметилметан (ДДТ). Несмотря на запрещение в большинстве стран причерноморского региона производства и сокращение использования ХОП в сельском хозяйстве еще в 70-х годах, а ПХБ в промышленности - с начала 90-х годов прошлого века, они по-прежнему загрязняют акваторию Чёрного моря. Одним из механизмов «выноса» ХОС из водной среды является извлечение их морскими организмами (Малахова и др., 2016, Никонова и др., 2017, Поликарпов, Егоров, 1986, Malakhova et al, 2014). Аккумулированию ХОС гидробионтами способствуют их гидрофобные и липофильные свойства, а также высокая устойчивость ПХБ и ХОП к разложению в условиях окружающей среды. В морских экосистемах происходит передача ХОС по пищевой цепи (Romero-Romero et al, 2017, Sun et al, 2017).

Верхним звеном трофической цепи в Черном море, как во всем Мировом океане, являются китообразные. Вопрос о загрязнении ХОС морских млекопитающих впервые был поднят в семидесятых годах 20-го столетия (George, Frear, 1966, Sladen et al, 1966). В середине 80-х годов прошлого века в морях, омывающих Европу, отмечалось особенно сильное загрязнение. Тогда у ластоногих и китообразных была зарегистрирована экстремально высокая концентрация п,п'-ДДТ и его метаболитов до 500 мкг $\Gamma^{-1}$ и ПХБ - до 2530 мкг $\Gamma^{-1}$ (Бобовникова и др., 1986).

Накапливающиеся в подкожно-жировой клетчатке ХОС не оказывают на организмы прямого токсичного действия, поскольку слой подкожного жира не 
участвует активно в метаболизме. Однако, при быстрой потере подкожного жира («аккумулятора энергии»), нередко встречающейся у морских млекопитающих в периоды интенсивного расходования энергии - размножения и при нехватке кормовых ресурсов, большое количество ХОС, накопленных в жировых тканях, активно вовлекаются в обменные процессы и вызывают отравление организмов животных.

Определение ХОС позволяет оценить патогенные эффекты инкорпорированных соединений, также, в связи с кумуляцией токсических веществ дельфины используются в качестве интегральных биоиндикаторов состояния морских экосистем и антропогенного загрязнения акваторий (Биркун мл. и др., 1993).

Впервые исследования содержания ХОП у трех видов черноморских китообразных были проведены в 90-ых годах XX-го века (Биркун мл. и др., 1993). Содержание ХОП было определено в подкожном жире у павших животных, обнаруженных при обходах побережья Крыма - у 19 морских свиней (азовок), 2 афалин и 2 белобочек. Исследования выявили содержание ХОП, сравнимое с таковым у дельфинов экологически неблагополучных морей.

С 90-ых годов и до настоящего времени загрязнению ХОС черноморских китообразных было посвящено еще ряд исследований (Gaina, 2010, Popa et al., 2008, Tanabe et al., 1997, Weij et al., 2010). в которых определялись концентрации ХОС в подкожном жире и других органах трех видов дельфинов.

В 2017 г. на крымском побережье было зарегистрировано значительное количество выбросов дельфинов (Логоминова и др., 2017). Среди обнаруженных животных преобладали морские свиньи $(75,1 \%)$, из них 30\% были детеныши, но также были обнаружены афалины (11,5\%) и белобочки (6,5\%). Точные причины выбросов животных удалось определить в единичных случаях. Одной из причин гибели животных могли быть инфекционные заболевания, которые часто наблюдаются у ослабленных животных, в организмах которых накоплена чрезвычайно высокая концентрация ПХБ (Hall et al., 2006). Во время выездов на места выбросов животных проводились отборы проб подкожно-жировой клетчатки для исследований.

Целью данной работы являлось определение содержания хлорорганических загрязнителей в подкожном жире черноморских китообразных, выброшенных на крымское побережье в 2017 г.

\section{Материалы и методы}

Объектами исследования являлись пробы подкожного жира морской свиньи (азовки) Phocoena phocoena relicta Abel, 1905, афалины Tursiops truncatus ponticus Barabasch, 1940 и белобочки Delphinus delphis ponticus Barabash-Nikiforov, 1935, обнаруженных в 2017 г. на черноморском побережье Крыма. Материал для исследования отбирался в ходе работы сети регистрации данных о китообразных и мониторинга контрольного участка побережья и акватории (РИМС-сети) на черноморском побережье Крыма (Логоминова и др., 2017). Описание животных, районы и даты отбора проб представлены в таблице 1.

Образцы подкожного жира отбирали на спине животных, за спинным плавником. У особи №6, кроме спинного подкожного жира, отобрали пробу брюшного жира (проба №6а). Образцы до анализа были заморожены и хранились при $-20^{\circ} \mathrm{C}$. Возраст определялся по морфологическим показателям.

ХОС определяли методом, описанным в работе (Muir et al., 2003). с некоторыми изменениями. Пробы подкожного жира (ворвани), массой около 200 мг, измельчали, смешивали с раствором внутреннего стандарта ПХБ 119 и заливали смесью гексана и ацетона (1:1). Жир азовок практически полностью растворялся в экстрагенте. 
Таблица 1.

Данные об исследованных китообразных

\begin{tabular}{|c|c|c|c|c|c|c|}
\hline $\begin{array}{l}\text { № } \\
\text { особи }\end{array}$ & $\begin{array}{c}\text { Дата отбора } \\
\text { проб }\end{array}$ & Вид & Пол & Возраст & $\begin{array}{c}\text { Размер, } \\
\text { м }\end{array}$ & Район отбора \\
\hline 1 & 24.06 .2017 & $\begin{array}{l}\text { Морская свинья } \\
\text { (азовка) }\end{array}$ & 우 & $\begin{array}{c}\text { новорожденная, } \\
\text { около 1-2 мес. }\end{array}$ & 1,00 & $\begin{array}{c}\text { п. Веселое, г. } \\
\text { Судак }\end{array}$ \\
\hline 2 & 11.07.2017 & $\begin{array}{l}\text { Морская свинья } \\
\text { (азовка) }\end{array}$ & 우 & около 3-4 мес. & 1,10 & $\begin{array}{c}\text { Капсельская } \\
\text { бухта, г. Судак }\end{array}$ \\
\hline 3 & 18.07 .2017 & белобочка & क & 1,5-2 года & 1,45 & г. Керчь \\
\hline 4 & 20.08 .2017 & белобочка & $0^{1}$ & около 8-10 лет & 1,75 & г. Судак \\
\hline 5 & 15.12 .2017 & белобочка & $\begin{array}{c}\text { не } \\
\text { опр. }\end{array}$ & не опр. & не опр. & $\begin{array}{c}\text { Капсельская } \\
\text { бухта, г. Судак }\end{array}$ \\
\hline 6 & 30.08 .2017 & афалина & $0^{\lambda}$ & 1,5-2 года & 2,20 & П. Новый Свет \\
\hline $6 a^{* *}$ & 30.08 .2017 & афалина & $\pi$ & 1.5-2 года & 2,20 & п. Новый Свет \\
\hline 7 & 10.12 .2017 & афалина & $\hat{0}$ & 1,5-2 года & 2,00 & г. Севастополь \\
\hline
\end{tabular}

Примечание: ${ }^{*}$ - не определяли; ${ }^{* *}$ - проба жира с брюшной части особи №6.

У афалин и белобочек остаток после растворения жира взвешивали, определяя таким образом нерастворимую часть пробы. Далее часть экстракта для отделения целевых аналитов от липидов пропускали через колонку с флорисилом, дезактивированным водой (1,5\% по массе). Аналиты из колонки элюировали гексаном. Другая часть экстракта была использована для определения массовой доли жиров экстракционно-весовым методом согласно ГОСТ 7636-85. Анализы проводили в двух повторностях.

Концентрацию ХОС определяли на газовом хроматографе Хроматэк Кристалл 5000 с микро-ЭЗД и капиллярной колонкой CR-5 (длина 30 м, диаметр 0,32 мм, слой фазы 0,5 мкм) в ЦКП «Спектрометрия и хроматография» ФГБУН ИМБИ. Расчет количественного содержания ХОС проводили методом градуировки. В качестве стандартных образцов использовали аттестованные ГСО $\alpha$-, $\beta$ - и $\gamma$-изомеров ГХЦГ, гексахлорбензола (ГХБ), п,п'-ДДТ и его метаболитов п,п'-ДДЭ и п,п'-ДДД (далее ДДТ, ДДЭ и ДДД), а также стандартный раствор фирмы Sigma-Aldrich шести индикаторных конгенеров ПХБ (по нумерации IUPAC): 28, 52, 101, 138, 153 и 180, рекомендованных Международным советом по изучению моря для мониторинга загрязненности морских экосистем. Полученные результаты представлены средним значением из двух повторностей и выражены в мкг· $\Gamma^{-1}$ сырой и липидной массы. Ошибка определения ХОС не превышала 20\%.

Пример фрагмента хроматограммы гексанового экстракта ворвани особи №3, полученного по вышеописанному методу, показан на рис. 1.

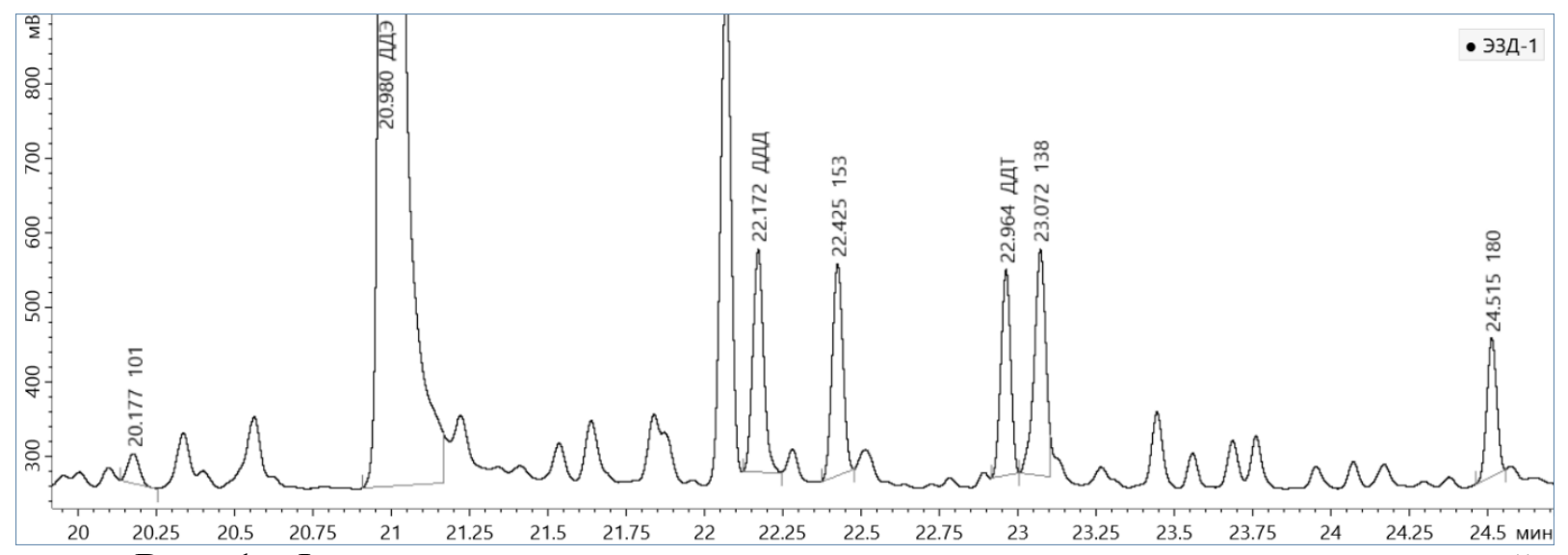

Рис. 1. Фрагмент хроматограммы гексанового экстракта подкожно-жировой клетчатки белобочки №3, полученной на ГХ Хроматэк-Кристалл 5000.2 с ДЭ3 
Для подтверждения идентификации искомых XOC, a также для получения дополнительной информации о загрязняющих веществах в пробах, экстракты проб были проанализированы на газовом хроматографе Хроматэк-Кристалл 5000.2 с массспектрометрическим детектором (ГX/MC) c электронной ионизацией. Анализ проводили в режиме сканирования по полному ионному току, идентификацию ХОС проводили путем сравнения времен удерживания и полученных масс-спектров с референтными спектрами библиотеки NIST'08.

\section{Результаты и их обсуждение}

Жирность образцов значительно отличалась. Исключительно высокой она была в подкожном сале азовки. У особи №1 жирность составляла 97,3\%, у №2 - 93,6\%, чем, очевидно, объясняется его особая мягкость. При этом жир азовок №1 и 2 отличался невысоким содержанием влаги - 2 и 6\%, соответственно. В пробах белобочки № 3,4 и 5 содержание липидов составляло 45, 49 и 81\%, влаги $-45,45$ и 7\% соответственно. В спинном подкожном жире афалины №6 содержание жира было ниже, чем в брюшной части и равнялось 57 и 76\%, у афалины №7 - 67\%, а влага в этих пробах составила 11, 6 и 7\% соответственно. Такое соотношение жира и влаги в пробах дельфинов, дает характеристику упитанности дельфинов и в целом свидетельствует об их состоянии до гибели. Известно, что содержание жира в подкожно-жировой клетчатке здоровой черноморской белобочки в среднем составляло 84, афалины - около 86, морской свиньи (азовки) - 95\% (Драгунов, Касинова, 1951). На основании этих данных можно предположить, что особи белобочки №3 и 4 были истощены.

Во всех пробах подкожно-жировой клетчатки обнаружены следующие ХОП: $\beta$ и $\gamma$-изомеры ГХЦГ, ГХБ, п,п'-ДДТ и его метаболиты п,п' -ДДД и п,п'-ДДЭ (табл. 2).

Таблица 2.

Концентрация ХОП в подкожном слое жира дельфинов, выброшенных на крымское побережье в 2017 г.

\begin{tabular}{|c|c|c|c|c|c|c|c|c|c|}
\hline \multirow{2}{*}{ 을 영 } & \multicolumn{9}{|c|}{ Концентрация ХОП, мкг·- $\Gamma^{-1}$ сырой массы / липидной массы* } \\
\hline & $\alpha-Г Х Ц Г ~$ & $\beta$-ГХЦГ & $\gamma$-ГХЦГ & $\sum$ ГХЦГ & ГХБ & п,п’-ДДЭ & п,п’-ДДД & п,п’-ДДТ & ¿ДДТ \\
\hline \multicolumn{10}{|c|}{ Морская свинья (азовка) } \\
\hline \multirow{2}{*}{1} & $\underline{0,003}$ & $\underline{0,027}$ & $\underline{0,005}$ & $\underline{0,035}$ & $\underline{0,29}$ & $\underline{0,85}$ & $\underline{0,30}$ & $\underline{0,07}$ & $\underline{1,23}$ \\
\hline & 0,003 & 0,028 & 0,006 & 0,036 & 0,30 & 0,88 & 0,31 & 0,08 & 1,27 \\
\hline \multirow{2}{*}{2} & & $\underline{0,042}$ & $\underline{0,008}$ & $\underline{0,050}$ & $\underline{0,43}$ & 1,71 & $\underline{0,58}$ & $\underline{0,18}$ & 2,49 \\
\hline & 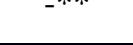 & 0,046 & 0,009 & 0,055 & 0,47 & 1,90 & 0,64 & 0,20 & 2,75 \\
\hline \multicolumn{10}{|c|}{ Белобочка } \\
\hline \multirow{2}{*}{3} & $\underline{0,011}$ & & $\underline{0,014}$ & $\underline{0,144}$ & $\underline{3,68}$ & $\underline{66,45}$ & $\underline{5,40}$ & $\underline{1,93}$ & $\underline{73,79}$ \\
\hline & 0,023 & $\underline{0,120} 0,264$ & 0,031 & 0,319 & 8,13 & 146,95 & 11,95 & 4,28 & 163,18 \\
\hline \multirow{2}{*}{4} & $\underline{0,003}$ & $\underline{0,100}$ & $\underline{0,005}$ & $\underline{0,108}$ & $\underline{3,95}$ & 65,50 & 1,60 & 1,22 & $\underline{68,32}$ \\
\hline & 0,007 & 0,207 & 0,009 & 0,223 & 8,14 & 134,84 & 3,28 & 2,52 & 140,64 \\
\hline \multirow{2}{*}{5} & $\underline{0,004}$ & $\underline{0,040}$ & - & $\underline{0,044}$ & $\underline{0,13}$ & $\underline{1,30}$ & $\underline{0,72}$ & $\underline{0,15}$ & 2,17 \\
\hline & 0,005 & 0,049 & - & 0,054 & 0,16 & 1,60 & 0,88 & 0,19 & 2,67 \\
\hline \multicolumn{10}{|c|}{ Афалина } \\
\hline \multirow{2}{*}{6} & $\underline{0,005}$ & $\underline{0,046}$ & $\underline{0,007}$ & $\underline{0,058}$ & $\underline{0,63}$ & $\underline{1,30}$ & $\underline{0,83}$ & $\underline{0,14}$ & 2,28 \\
\hline & 0,005 & 0,047 & 0,008 & 0,059 & 0,65 & 1,34 & 0,86 & $\overline{0,14}$ & 2,34 \\
\hline \multirow{2}{*}{$6 a$} & $\underline{0,008}$ & $\underline{0,071}$ & $\underline{0,009}$ & $\underline{0,088}$ & $\underline{0,92}$ & 2,33 & $\underline{0,58}$ & $\underline{0,20}$ & 3,12 \\
\hline & 0,011 & 0,106 & 0,013 & 0,130 & 1,37 & 3,47 & 0,86 & 0,30 & 4,63 \\
\hline \multirow{2}{*}{7} & $\underline{0,004}$ & $\underline{0,067}$ & $\underline{0,004}$ & $\underline{0,074}$ & $\underline{0,09}$ & $\underline{4,16}$ & $\underline{0,76}$ & $\underline{0,29}$ & $\underline{5,20}$ \\
\hline & 0,005 & 0,088 & 0,005 & 0,098 & 0,12 & 5,47 & 1,00 & 0,38 & 6,85 \\
\hline
\end{tabular}

Примечание: * верхняя цифра - содержание ХОП в сырой массе подкожного жира, нижняя цифра - содержание ХОП в липидной массе, ** - не обнаружено. 
В целом концентрация ХОП в пробах подкожного жира дельфинов уменьшалась в ряду: п,п'-ДДЭ >> п,п'-ДДД > ГХБ > п,п'-ДДТ > $\beta$-ГХЦГ > $\gamma$-ГХЦГ $>\alpha$-ГХЦГ. Максимальная концентрация всех ХОП обнаружена в пробах белобочки №3 и 4, минимальная - в пробе новорожденной азовки №1.

Во всей выборке доминирующим хлорпестицидом был ДДЭ, концентрация которого изменялась от 0,88 до 146,95 мкг $\Gamma^{-1}$ липидной массы, что составляло от 44 до 90\% от суммы ХОП. Наибольшее содержание ДДЭ определено в пробах белобочки №3 и 4, у остальных исследованных особей концентрация была ниже в среднем в 30 раз. По-видимому, такая значительная разница в степени загрязненности определяется особенностями питания и физиологического состояния (истощением организма) белобочек №3 и 4.

Сравнение полученных результатов с данными 1990-х гг. показало, что в подкожном жире у белобочек №3 и 4 содержание п,п’-ДДЭ было на порядок выше, чем у черноморских белобочек в 1990 г., когда в их жире максимальная концентрация п,п'ДДЭ составляла 14,41 мкг· $\Gamma^{-1}$ (Биркун мл. и др., 1993).В то же время, концентрация п,п'ДДЭ у белобочки №5 оказалась на порядок ниже, чем у дельфинов этого вида в 1990 г.

В атлантических прибрежных районах Испании в 1994-1996 гг. загрязненность ДДЭ в жире белобочек была ниже в 7 раз, чем у особей №3 и 4. Однако в межматериковом Средиземном море концентрация п,п'-ДДЭ в тот период была сопоставима с загрязненностью особей №3 и №4 и составила в среднем 24,68+/-31,22, при максимальной 130,40 мкг· $\Gamma^{-1}$ липидной массы (Borrell et al., 2001).

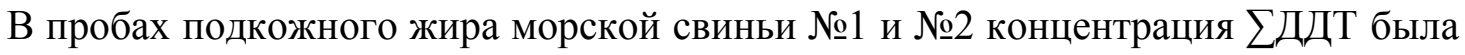
ниже почти на два порядка, чем у белобочки (табл. 2), и составляла в среднем 1,86 мкг $\Gamma^{-1}$ сырой массы. Такая загрязненность оказалась в среднем в 50 раз ниже

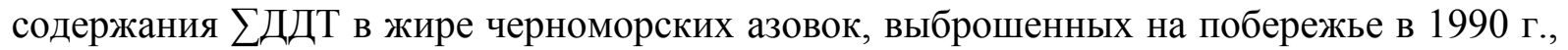
максимальное значение которого достигало 243,75 мкг· $\Gamma^{-1}$ (Биркун мл. и др., 1993). и исследованных в 1997 г., максимальное значение которого достигало 180 мкг· $\Gamma^{-1}$ сырой

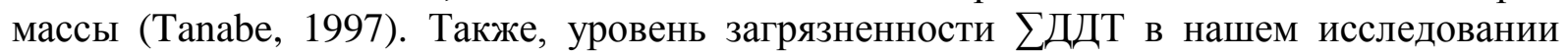
оказался в среднем в 27 раз ниже, чем у молодых азовок, обнаруженных на побережье в 1998 г., максимальное значение которого в жире достигало 81,709 мкг· $\Gamma^{-1}$ липидной массы (Weij et al., 2010).

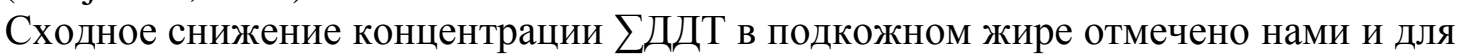
афалины - уровень загрязнения в настоящем исследовании в среднем на порядок ниже, чем у афалин, выброшенных на крымское побережье в 1990 г., максимальное значение которого достигало 65,61 мкг· $\Gamma^{-1}$ (Биркун мл. и др., 1993).

По-видимому, значительное снижение концентрации ДДТ в подкожном жире азовки и афалины определяется понижением в настоящее время содержания ДДТ в объектах питания этих видов китообразных.

Интервал концентрации ГХБ в пробах составил 0,12-8,14 мкг· $\Gamma^{-1}$ липидной массы (табл. 2). Также, как и для ДДТ с метаболитами, максимальные значения ГХБ $(8,13$ и 8,14 мкг $\Gamma^{-1}$ липидной массы), резко отличающиеся от значений в других пробах, обнаружены в пробах белобочек №3 и №4. Концентрация ГХБ в подкожном жире азовки оказалась существенно ниже и составляла в среднем 0,39 мкг. $\Gamma^{-1}$ липидной массы, что было сопоставимо с данными 1998 г., когда содержание ГХБ в ворвани взрослых особей морских свиней изменялось в диапазоне от 0,49 до 0,93, а детенышей - от 0,40 до 0,77 мкг· $\Gamma^{-1}$ липидной массы (Tanabe et al., 1997). Полученные нами данные о содержании ГХБ в пробах афалин (интервал 0,09-0,92 мкг· $\Gamma^{-1}$ сырой массы) также сравнимы с данными 1990 года (интервал 0,08-0,39 мкг· $\Gamma^{-1}$ ) (Биркун мл. и др., 1993). Известно, что с 1990 г. существует ограничение и сокращение глобального производства и использования ГХБ (UNEP 2001). Однако из полученных данных можно заключить, что ГХБ продолжает загрязнять Черное море. 
В сумме ХОП наименьшие концентрации зарегистрированы для ГХЦГ. Концентрация его трех изомеров изменялась в диапазоне 0,035-0,144 мкг $\Gamma^{-1}$ сырой

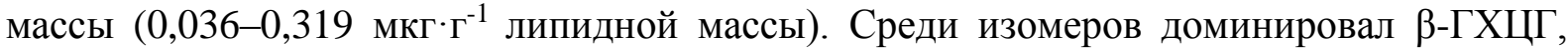
доля которого составляла в среднем 85\%. Крайне высокая концентрация ГХЦГ была обнаружена в подкожном жире морских свиней (данные 1993 г.), выброшенных на турецкое побережье, составляющая в среднем 9,25 мкг. $\Gamma^{-1}$ сырой массы (Tanabe et al., 1997), в пробах, выброшенных на побережье Крыма в 1990 г. морских свиней (в

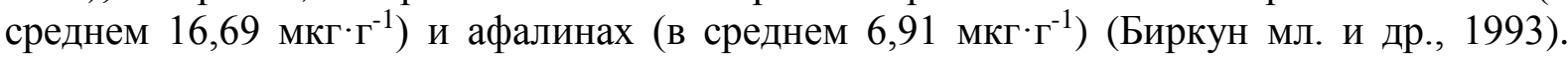
Весьма высока была концентрация ГХЦГ и у белобочек, выброшенных в 1990 году на побережье Крыма (составляла в среднем 1,75 мкг. ${ }^{-1}$ ) (Биркун мл. и др., 1993). По

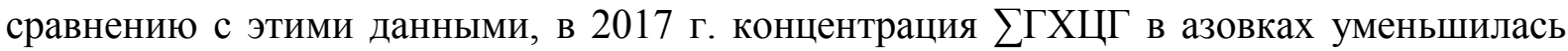
почти в 200 раз, у афалин - почти в 100 раз, у белобочек - почти в 18 раз. Сниженный уровень загрязненности, подтверждает тот факт, что ГХЦГ в Черном море в настоящее время поступает в значительно меньшем количестве, чем в конце прошлого века.

Второй группой ХОС по уровню загрязнения жира после триады ДДТ были ПХБ. Во всех пробах обнаружены ПХБ 52, 101, 138, 153, 180 (табл. 3).

Таблица 3.

Концентрация конгенеров ПХБ в подкожном слое жира дельфинов, выброшенных на крымское побережье в 2017 г.

\begin{tabular}{|c|c|c|c|c|c|c|c|}
\hline \multirow[t]{2}{*}{ № особи } & \multicolumn{7}{|c|}{$\begin{array}{c}\text { Концентрация конгенеров ПХБ, } \\
\text { мкг } \cdot \Gamma^{-1} \text { сырой массы / липидной массы* }\end{array}$} \\
\hline & 28 & 52 & 101 & 153 & 138 & 180 & $\sum \Pi X Б_{6}$ \\
\hline \multicolumn{8}{|c|}{ Морская свинья (азовка) } \\
\hline \multirow{2}{*}{1} & $\underline{0,004}$ & 0,11 & 0,08 & 0,12 & 0,08 & $\underline{0,02}$ & 0,41 \\
\hline & $\overline{0,004}$ & $\overline{0,12}$ & $\overline{0,10}$ & $\overline{0,12}$ & $\overline{0,08}$ & $\overline{0,02}$ & $\overline{0,42}$ \\
\hline \multirow{2}{*}{2} & ** & 0,13 & $\underline{0,16}$ & $\underline{0,23}$ & $\underline{0,18}$ & $\overline{0,04}$ & $\underline{0,73}$ \\
\hline & & $\overline{0,14}$ & $\overline{0,18}$ & $\overline{0,25}$ & $\overline{0,20}$ & $\overline{0,04}$ & $\overline{0,81}$ \\
\hline \multicolumn{8}{|c|}{ Белобочка } \\
\hline \multirow{2}{*}{3} & & 0,98 & $\underline{0,86}$ & $\underline{5,10}$ & $\underline{3,61}$ & 1,68 & 12,23 \\
\hline & - & $\overline{2,16}$ & $\overline{1,89}$ & $\overline{11,28}$ & $\overline{7,99}$ & $\overline{3,72}$ & $\overline{27,04}$ \\
\hline \multirow[b]{2}{*}{4} & 0,011 & 0,72 & 0,68 & 4,87 & 4,08 & 1,23 & 11,60 \\
\hline & $\overline{0,022}$ & $\overline{1,48}$ & $\overline{1,41}$ & $\overline{10,03}$ & $\overline{8,40}$ & $\overline{2,54}$ & $\overline{23,88}$ \\
\hline \multirow{2}{*}{5} & 0,017 & 0,08 & $\underline{0,08}$ & $\underline{0,13}$ & $\underline{0,10}$ & 0,02 & $\underline{0,43}$ \\
\hline & $\overline{0,021}$ & $\overline{0,09}$ & $\overline{0,10}$ & $\overline{0,16}$ & $\overline{0,13}$ & $\overline{0,03}$ & $\overline{0,53}$ \\
\hline \multicolumn{8}{|c|}{ Афалина } \\
\hline \multirow{2}{*}{6} & 0,019 & 0,11 & $\underline{0,13}$ & $\underline{0,26}$ & 0,20 & $\underline{0,04}$ & $\underline{0,76}$ \\
\hline & 0,034 & $\overline{0,18}$ & $\overline{0,23}$ & $\overline{0,45}$ & $\overline{0,351}$ & $\overline{0,08}$ & $\overline{1,33}$ \\
\hline \multirow{2}{*}{$6 \mathrm{a}$} & $\underline{0,025}$ & $\underline{0,11}$ & $\underline{0,19}$ & $\underline{0,31}$ & $\underline{0,31}$ & $\underline{0,04}$ & $\underline{0,99}$ \\
\hline & 0,037 & 0,16 & $\overline{0,28}$ & $\overline{0,46}$ & $\overline{0,47}$ & 0,07 & $\overline{1,47}$ \\
\hline \multirow[b]{2}{*}{7} & $\underline{0,005}$ & $\underline{0,11}$ & $\underline{0,23}$ & $\underline{0,72}$ & $\underline{0,57}$ & $\underline{0,15}$ & $\underline{1,79}$ \\
\hline & 0,006 & 0,14 & $\overline{0,30}$ & $\overline{0,95}$ & $\overline{0,75}$ & 0,20 & 2,35 \\
\hline
\end{tabular}

Примечание:

* верхняя цифра - содержание конгенеров ПХБ в сырой массе подкожного жира, нижняя цифра - содержание конгенеров ПХБ в липидной массе, ${ }^{* *}-$ не обнаружено.

Концентрация $\sum$ ПХБ6 изменялась в широком диапазоне от 0,42 мкг $\Gamma^{-1}$ в пробе от новорожденной азовки до 27,04 мкг· $\Gamma^{-1}$ липидной массы в пробе от белобочки №3. Минимальная концентрация определена для трихлорбифенила 28, максимальная гексахлорированных бифенилов 153 и 138. Сумма концентрации данных конгенеров вместе с ПХБ 180 изменялась от 0,22 до 22,99 мкг· $\Gamma^{-1}$ липидной массы, при этом их минимальная концентрация наблюдалась в пробах детенышей азовок (табл. 3).

Известны данные по содержанию ПХБ в пробах подкожного жира азовки Черного моря в 1993 г. Тогда концентрация суммы ПХБ изменялась в диапазоне 47-160 мкг $\Gamma^{-1}$ липидной массы. Максимальная концентрация была определена для ПХБ 138, 
153 и 180, их доля в сумме ПХБ составляла 41\%, что соответствует 18-68 мкг. $\Gamma^{-1}$ липидной массы (Tanabe et al., 1997).

На рис. 2 показана доля каждого обнаруженного конгенера ПХБ в пробах жира. Как видно, преобладающими конгенерами, как и в конце прошлого века, в сумме ПХБ были гексахлорбифенилы 153 и 138. Их доля составляла в среднем 35 и 27\% соответственно (рис. 2).

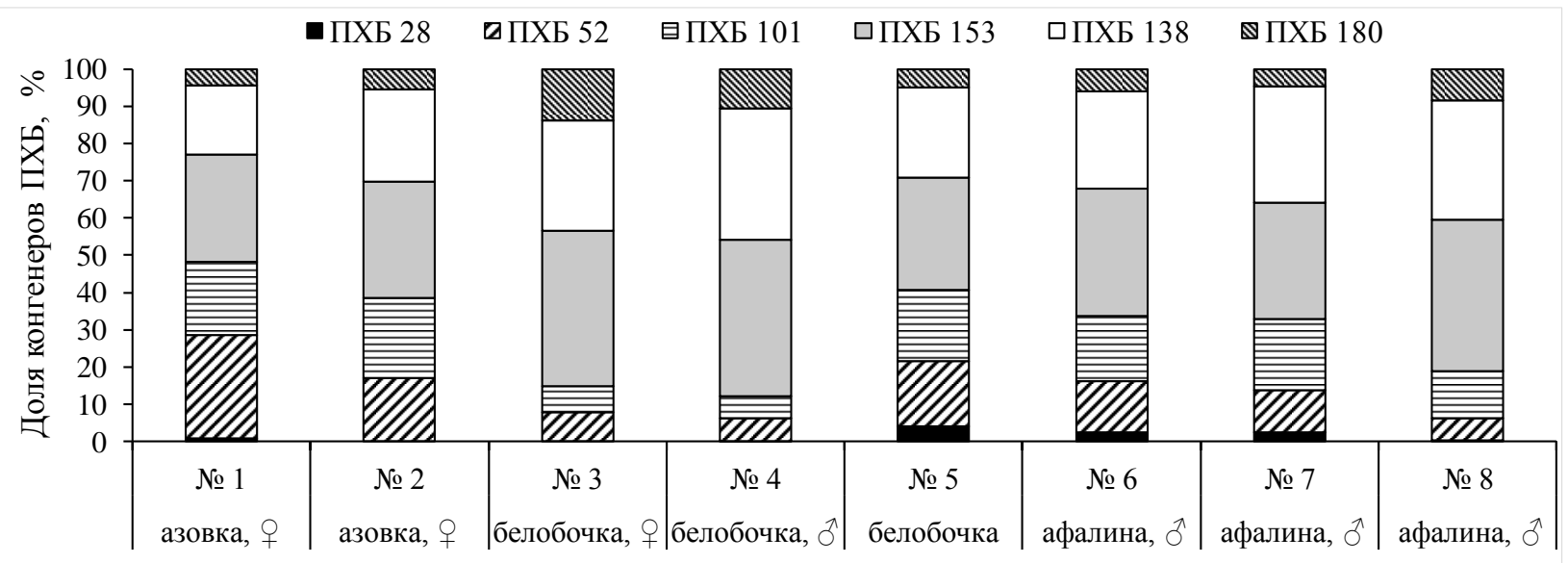

Номер пробы, вид и пол животных

Рис. 2. Процентный вклад шести конгенеров ПХБ в сумму концентрации $\sum$ ПХБ6 в подкожном жире китообразных Черного моря в 2017 г.

Сравнение содержания конгенеров ПХБ 138, 153 и 180 в жире черноморских азовок-детенышей в 1993 г. (Tanabe et al., 1997). с уровнем их концентрации в особях детенышей азовок №1 и 2 показывает более низкий уровень загрязненности ПХБ в 2017 г. (рис. 3). По-видимому, снижение уровня загрязнения хлорорганическими токсикантами компонентов экосистем Черного моря (Малахова и др., 2006). сказывается и на уменьшении содержания ПХБ в тканях молодых азовок.

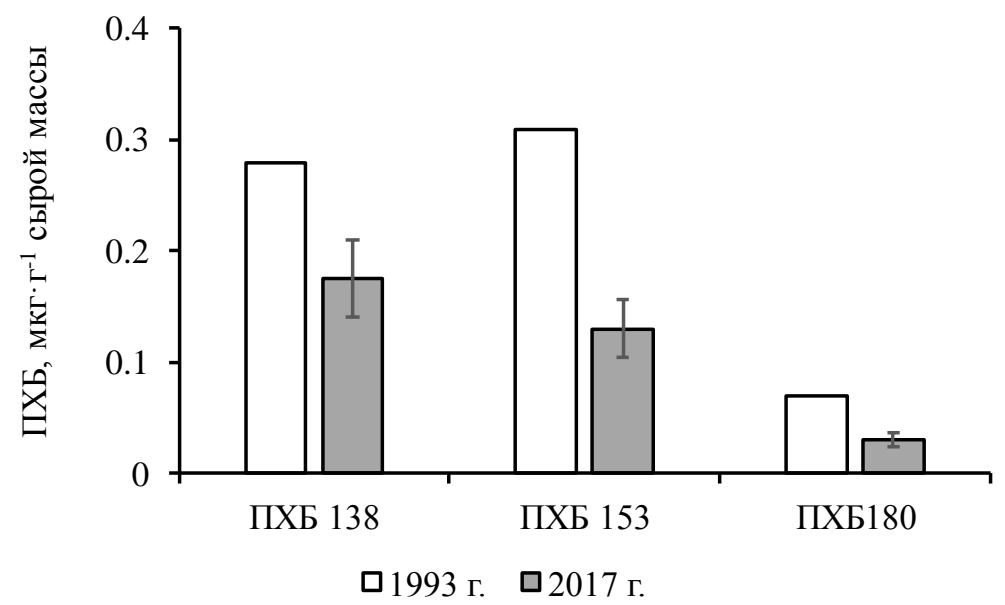

Рис. 3. Средняя концентрация конгенеров ПХБ 138, 153 и 180 в подкожном жире детенышей черноморских азовок в 1993 (Tanabe et al., 1997) и 2017 гг. (настоящее исследование). Вертикальные отрезки показывают погрешность измерения.

Относительно двух других видов черноморских дельфинов такой вывод сделать нельзя. Концентрация $\sum П Х Б_{6}$ в подкожном жире афалины превышает в среднем почти

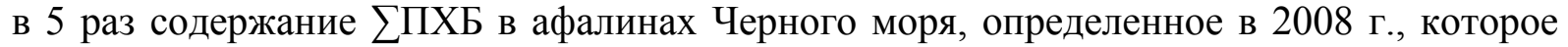
тогда составляло 0,37 мкг $\Gamma^{-1}$ липидной массы (Popa et al., 2008). Также, наши данные относительно содержания конгенеров ПХБ сравнимы с данными исследований 2007- 
2010 гг. (Gaina, 2010) в котором определенные концентрации конгенеров ПХБ у самцов черноморской афалины превышают наши данные в среднем в несколько раз.

В последнем исследовании (Gaina, 2010) приведены данные и по конгенерам ПХБ белобочек; концентрации преобладающих конгенеров ПХБ 153,138 для самцов - в среднем 0,49 ПХБ 153 мкг $\Gamma^{-1}$ и 0,33 мкГ $\Gamma^{-1}$ ПХБ 138, и для самок - ПХБ 153 в среднем 1,04 мкг $\Gamma^{-1}$ и ПХБ138 - 1,231 мкг $\Gamma^{-1}$. Эти концентрации в 3-10 раз ниже полученных нами для белобочек №3 и 4; в то же время в 3-10 раз выше для белобочки №5.

Нормированных значений по уровню загрязненности тканей морских млекопитающих не установлено. Однако отмечено, что высокая концентрация ПХБ в ворвани морской свиньи $\left(\sum П Х Б_{25}=27,6\right.$ мкг. $\Gamma^{-1}$ липидной массы) снижает их устойчивость к инфекционным заболеваниям (Jepson et al., 2005). Высокие концентрации ПХБ в подкожном жире белобочек №3 и 4, как и ДДТ и ГХБ, сочетанные с низким содержанием липидов позволяют сделать предположение об их гибели от инфекционного заболевания, Не исключено, что инфекционным агентом мог служить

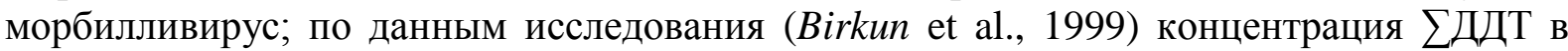
подкожном жире двух белобочек, погибших от морбилливирусной инфекции, была в 50-100 раз выше, чем у зубатых китообразных Северного моря, Северной Атлантики и Балтийского моря.

Высокие концентрации всех ХОС, кроме ГХЦГ, в пробах подкожного жира упомянутых двух белобочек по сравнению с остальными исследованными нами животными, связаны, на наш взгляд, прежде всего, с выбором объектов питания. Указанные высокие концентрации ХОС позволяют говорить о сохраняющемся загрязнении экосистем Черного моря, как минимум, очаговом.

\section{Выводы}

Концентрация ХОС в пробах подкожного жира дельфинов Черного моря в 2017 г., выброшенных на берег Крыма уменьшалась в ряду: п,п'-ДДЭ > $\sum$ ПХБ6 $>$ п,п’ДДД $>$ ГХБ $>$ п,п'-ДДТ $>\beta$-ГХЦГ $>\gamma$-ГХЦГ $>\alpha$-ГХЦГ. Максимальные концентрации ХОС обнаружены в подкожном жире взрослых белобочек, минимальная - в пробе ворвани новорожденной азовки. Сравнение с данными конца XX века показало существенное снижение концентрации ДДТ и ГХЦГ в подкожном жировом слое азовки и афалины. В то же время, концентрации ГХБ у всех трех видов черноморских китообразных не изменились. Содержание ПХБ в ворвани детенышей азовки снизилось по сравнению с данными 1993 г., существенно не изменилось у белобочки и афалины. Концентрации метаболитов ДДТ - ДДЭ и ДДД, а также ГХБ и ПХБ в жире отдельных особей находятся на уровнях, которые могут приводить к снижению устойчивости морских млекопитающих к инфекционным заболеваниям.

Работа подготовлена по темам государственных заданий ФГБУН ИМБИ «Молисмологические и биогеохимические основы гомеостаза морских экосистем», номер регистрации АААА-А18-118020890090-2 и ФГБУН «Карадагская научная станция им. Т.И.Вяземского - природный заповедник РАН» «Адаптивные и согласованные со средой методы обработки гидроакустической информации морскими млекопитающими», номер - АААА-Ф16-116022510085-1.

\section{Список литературы}

1. Биркун А.А. мл., Никитина В.Н, Кривохижин С.В., Демченко В.Д., Давидюк Е.И. Хлорорганические пестициды в жире черноморских дельфинов // Ветеринария. 1993. - №6. - C.50-52.

2. Бобовникова Ц.И., Вирченко Е.П., Дибцева А.В., Яблоков А.В., Солнцева Г.Н., 
Пастухов В.Д. Водные млекопитающие - индикаторы присутствия хлорорганических пестицидов и полихлорированных бифенилов в водной среде // Гидробиологический журнал. - 1986. - Т. 22. - №2. - С. 63-66.

3. Драгунов А.М., Касинова И.Е. Весовой и химический состав дельфинов Черного моря // Рыбное хозяйство. - 1951. - №11. - С. 58-60.

4. Логоминова И.В., Артов А.М., Коростелева А. В., Постникова А. Н. Итоги работы сети регистрации и мониторинга выбросов китообразных на побережье Крыма в 2017 году // Труды Карадагской научной станции им. Т.И. Вяземского - природного заповедника РАН. - 2017. - № 2(4). - С. 55-69.

5. Малахова Л.В., Малахова Т.В., Егоров В.Н., Гулин С.Б., Сидоров И.Г., Игнатов Е.И. Хлорорганические углеводороды в компонентах севастопольских бухт в начале XXI века // Использование и охрана природных ресурсов в России. - 2016. - №1. - С. 6671.

6. Никонова Л.Л., Малахова Л.В., Нехорошев М.В., Рябушко В.И. Хлорорганические соединения в гонадах и половых продуктах двустворчатого моллюска мидии Mytilus galloprovincialis Lam., культивируемого у берегов Крыма (Черное море) // Вода: химия и экология. -2017 . - № 3. - С. 40-45.

7. Поликарпов Г.Г., Егоров В.Н. Морская динамическая радиохемоэкология. - М.: Энергоатомиздат, 1986. - $151 \mathrm{c.}$

8. Birkun A.A., Kuiken, T., Krivokhizhin S., Haines D.M., Osterhaus A.D.M.E., van de Bildt M.W.G., Joiris C.R., Siebert U. Epizootic of morbilliviral disease in common dolphins (Delphinus delphis ponticus) from the Black Sea // Veterinary Record. - 1999. -№ 144. P. 85- 92 .

9. Borrell A., Cantos G., Pastor T., Aguilar A. Organochlorine compounds in common dolphins (Delphinus delphis) from the Atlantic and Mediterranean waters of Spain // Environmental Pollution. - 2001. - № 114(2). - P. 265-274.

10. Gaina N. Morphological and functional research regarding the reproduction of the Black Sea dolphins. Summary of the PHD Thesis. University of Agricultural Science and Veterinary Medicine. Cluj-Napoca Doctoral School, Faculty of Veterinary Medicine. Cluj-Napoca, 2010. - $32 \mathrm{p}$.

11. George, J. L., Frear D.E.H. Pesticides in the Antarctic // Journal of Applied Ecology (supplement). - 1966. - P. 155-167.

12. Hall A.J., Hugunin K., Deaville R., Law R.J., Allchin C.R., Jepson P.D. The risk of infection from polychlorinated biphenyl exposure in harbor porpoise (Phocoena phocoena): a case-control approach // Environmental Health Perspectives. - 2006. №114. -P. 704-711.

13. Jepson P.D., Bennet P.M., Deaville R., Allchin C.R., Baker J.R., Law R.J. Relationships between polychlorinated biphenyls and health status in harbor porpoises (Phocoena phocoena) stranded in the United Kingdom // Environmental Toxicology and Chemistry. - 2005. - №24. - P. 238 - 248.

14. Malakhova L., Giragosov V., Khanaychenko A., Malakhova T., Egorov V., Smirnov V. Partitioning and level of organochlorine compounds in the tissues of the Black Sea Turbot at the South-Western Shelf of Crimea // Turkish Journal of Fisheries and Aquatic Sciences. - 2014. - №14. - P. 993-1000. doi: 10.4194/1303-2712-v14_4_19.

15. Muir D., Savinova T., Savinov V., Alexeeva L., Potelov V., Svetochev V. Bioaccumulation of PCBs and chlorinated pesticides in seals, fishes and invertebrates from the White Sea, Russia // Science of the Total Environment. - 2003. - № 306 (1-3). - P. 111-131.

16. Popa O. M., Trif A., Marin N., Ursu N. Organochlorine pesticides in the Black Sea dolphins // Lucrări Ştiinłifice Medicină Veterinară. - 2008. - T. 41. - P. 768-773. 
17. Romero-Romero S., Herrero L., Fernández M., Gómara B., Acuña J. L. Biomagnification of persistent organic pollutants in a deep-sea, temperate food web // Science of the Total Environment. - 2017. - № 605. - P. 589-597.

18. Sladen W. J. L., Menzie C. M., Reichel W. L. DDT residues in Adelie penguins and a crabeater seal from Antarctica // Nature. - 1966. - № 210. - P. 670-673.

19. Sun Y.X., Hu Y.X., Zhang Z.W., Xu X.R., Li H.X., Zuo L.Z., Zhong Y., Sun H., Mai B.X. Halogenated organic pollutants in marine biota from the Xuande Atoll, South China Sea: Levels, biomagnification and dietary exposure // Marine pollution bulletin. - 2017. №118(1-2). - P. 413-419.

20. Tanabe S., Madhusree B., Amaha A.O., Tatsukawa R., Miyazaki N., Ozdamar E., Aral O., Samsun O., Ozturk B.. Persistent organochlorine residues in harbour porpoise (Phocoena phocoena) from the Black Sea // Marine Pollution Bulletin. - 1997. - №34(5). - P. 338-347.

21. Tanabe, S., Madhusree, B., Amaha, A.O., Tatsukawa, R., Miyazaki, N., Ozdamar, E., Aral, O., Samsun, O., Ozturk, B. Isomer-specific analysis of polychlorinated biphenyls in harbour porpoise (Phocoena phocoena) from the Black Sea // Marine Pollution Bulletin. 1997. - № 34(9). - P. 712-720.

22. UNEP 2001. Final Act of the Plenipotentiaries on the Stockholm Convention on Persistent Organic Pollutants. United Nations Environment Program Chemicals. [Электронный pecypc]. Режим доступа: www.pop.int

23. Weij L., Das K., Neels H., Blust R., Covaci A. Occurrence of anthropogenic and naturallyproduced organohalogenated compounds in tissues of Black Sea harbour porpoises // Marine pollution bulletin. - 2010. - № 60(5). - P. 725-731.

\title{
NEW DATA ON ORGANOCHLORINE POLLUTANTS IN THE SUBCUTANEOUS FAT OF THE BLACK SEA CETACEANS
}

\author{
Logomonova I.V. ${ }^{1}$, Malachova L.V. ${ }^{2}$, Malachova T.V. ${ }^{2}$, Artov A.M. ${ }^{1}$, Korosteleva A.V. ${ }^{3}$, \\ Postnikova A.N. ${ }^{3}$ \\ ${ }^{\text {I}}$ T.I.Vyazemsky Karadag Scientific Station - Nature Reserve of the RAS, \\ Kurortnoe, Feodosia, Russian Federation, \\ ${ }^{2}$ The A.O. Kovalevsky Institute of Marine Biological Research of the RAS, \\ Sevastopol, Russian Federation, \\ ${ }^{3}$ Center for the Study, Rescue and Rehabilitation of Marine Mammals "Serene Sea", \\ Moscow, Russian Federation \\ e-mail:logominova@rambler.ru,malakh2003@list.ru,t.malakhova@imbr-ras.ru, \\ aartov06@gmail.com, sereneseadolphins@gmail.com
}

The data on the content of organochlorine pesticides (OCPs) and polychlorinated biphenyls (PCBs) in the subcutaneous fat layer of the Black Sea dolphins - bottlenose dolphins, white stallions and porpoises (Azovka) thrown on the Crimean coast in 2017 are presented. In all studied samples, $\alpha-, \beta-$, and $\gamma-\mathrm{HCH}$ were detected in the concentration range from 0.003 to 264 ( $\sum \mathrm{HCH}$ from 0.036 to 0.319 ); hexachlorobenzene - from 0.12 to 8.14; p, p'-DDT and its metabolites p, p'-DDE and p, p'-DDD from 0.08 to 146.95 (DDT from 27 to 163.18); and six polychlorinated biphenyls congeners (according to IUPAC: 28, 52, 101, 138, 153, and 180) - from 0.004 to 11.28 ( $\sum$ PHB6 from 0,42 to 27.04) $\mu \mathrm{g} g-1$ lipid mass. The proportion of $\mathrm{n}, \mathrm{p}$ '-DDE ranged from 44 to $90 \%$ the total OCP and reached $146.95 \mu \mathrm{g} \mathrm{g}-1$ lipid mass. The maximum concentration of OCPs and PCBs was recorded in the samples of subcutaneous fat of the common dolphins (Delphinus delphis ponticus BarabaschNikiforov, 1935).

Keywords: Common dolphin, bottlenose dolphin, harbour porpoise, hexachlorobenzene, DDT, DDE, polychlorinated biphenyls, Black Sea 